\title{
PENGARUH PROBLEM-BASED LEARNING TERHADAP PEMAHAMAN KONSEP DAN PEMECAHAN MASALAH DALAM MATERI HUKUM ARCHIMEDES
}

\author{
Rupus Kertinus ${ }^{1}$, Yudi Darma ${ }^{2}$, Wahyudi $^{3}$ \\ ${ }^{1,3}$ Program Studi Pendidikan Fisika, Fakultas Pendidikan MIPATEK, IKIP PGRI Pontianak \\ ${ }^{2}$ Program Studi Pendidikan Matematika, Fakultas Pendidikan MIPATEK, IKIP PGRI Pontianak \\ Jalan Ampera Nomor 88 Pontianak - 78116 \\ 1e-mail: rupuskertinus@gmail.com
}

\begin{abstract}
Abstrak
Penelitian bertujuan untuk menguji pengaruh model pembelajaran problem-based learning terhadap pemahaman konsep dan pemecahan masalah materi hukum Archimedes di kelas XI IPA SMA Negeri 1 Ketungau Tengah. Penelitian menggunakan quasi-experimental designs dengan nonequivalent groups posttest only. Instrumen yang digunakan adalah butir soal pemahaman konsep berbentuk tes pilihan ganda dan pemecahan masalah berbentuk tes uraian. Populasi penelitian seluruh siswa kelas XI IPA SMA Negeri 1 Ketungau Tengah tahun pelajaran 2018/2019. Sampel sebanyak 37 orang siswa yang terdiri dari dua kelas yang diambil dengan teknik cluster random sampling. Analisis data menggunakan uji MANOVA dua arah. Hasil penelitian: (1) Kemampuan pemahaman konsep siswa cukup dan pemecahan masalah siswa baik setelah diterapkannya model pembelajaran problem-based learning; (2) Kemampuan pemahaman konsep siswa kurang dan pemecahan masalah siswa sangat kurang setelah diterapkannya model pembelajaran konvesional; dan (3) Terdapat pengaruh model pembelajaran problembased learning terhadap pemahaman konsep dan pemecahan masalah materi hukum archimedes.
\end{abstract}

Kata Kunci: problem-based learning, pemahaman konsep, pemecahan masalah.

\begin{abstract}
The research aims to examine the effect of the problem-based learning model of learning on concept understanding and problem-solving of Archimedes material in class XI IPA of SMA Negeri 1 Ketungau Tengah. The research used quasiexperimental designs with nonequivalent groups posttest only. The instrument used was a matter of understanding the concept in the form of multiple-choice tests and problem-solving in the form of description tests. The population of the research was all students of class XI IPA of SMA Negeri 1 Ketungau Tengah in the academic year 2018/2019. A sample of 37 students consisted of two classes taken cluster random sampling technique. Data analysis using the MANOVA two-way test. The results of the research: (1) The ability to understand students' concepts is sufficient and students' problem-solving is good after the application of the problem-based learning model; (2) The ability to understand students' concepts is lacking and students' problem-solving is very lacking after the application of conventional learning models; and (3) There is an influence of the problem-based learning model on the understanding of concepts and problem-solving in Archimedes material.
\end{abstract}

Keywords: problem-based learning, concept understanding, problem-solving. 


\section{PENDAHULUAN}

Pendidikan mempunyai peranan yang sangat penting dalam kehidupan bangsa (Pradyumnati dalam Nafiah, 2016). Hal tersebut dipertegas oleh Darma dan Sujadi (2014) menyatakan bahwa salah satu strategi untuk meningkatkan kualitas sumber daya manusia adalah memposisikan sektor pendidikan sebagai alat utama dalam pembangunan. Salah satu mata pelajaran dalam pendidikan di Indonesia yang dipelajari pada tingkat sekolah menengah adalah Fisika.

Mundilarto (Sandra, dkk., 2010) mengemukakan bahwa Fisika sebagai ilmu dasar memiliki karakteristik yang mencakup bangun ilmu yang terdiri atas fakta, konsep, prinsip, hukum, postulat, dan teori serta metodologi keilmuan. Fisika merupakan mata pelajaran yang memerlukan pemahaman daripada penghafalan, tetapi diletakkan pada pengertian dan pemahaman konsep yang dititikberatkan pada proses terbentuknya pengetahuan melalui penemuan, penyajian data secara matematis, dan berdasarkan aturan-aturan tertentu, sehingga dalam mempelajarinya perlu aturan tertentu (Depdiknas dalam Sutarto, dkk., 2014).

Berns dan Erickson (Nursyarifah, dkk., 2018) menyatakan dalam suatu domain belajar, pemahaman merupakan prasyarat mutlak untuk tingkatan kemampuan kognitif yang tinggi, aplikasi, analisis, sintesis, dan evaluasi. Bloom (Hamdani, dkk., 2012) mengatakan bahwa pemahaman konsep adalah kemampuan menangkap pengertian-pengertian seperti mampu mengungkapkan suatu materi yang disajikan kedalam bentuk yang lebih dipahami, mampu memberikan interpretasi, dan mampu mengaplikasikannya. Hal tersebut dapat menjadikan siswa mudah dalam menyelesaikan soal-soal Fisika.

Selain pemahaman konsep, salah satu kemampuan yang diperlukan siswa dalam belajar adalah kemampuan pemecahan masalah. Kemampuan pemecahan masalah merupakan kemampuan dalam menyelesaikan soal-soal Fisika. Kemampuan memecahkan masalah sangat dibutuhkan oleh siswa dikarenakan pada dasarnya siswa harus berusaha sendiri mencari pemecahan masalah serta pengetahuan yang menyertainya, menghasilkan pengetahuan yang benar-benar bermakna (Trianto dalam Hertiavi, dkk., 2010). 
Mukminan (2013) mengemukakan salah satu kompetensi yang harus dimiliki dalam implementasi kurikulum 2013 adalah kemampuan berpikir kritis. Pemecahan masalah yaitu mampu berpikir secara kritis, lateral, dan sistemik, terutama dalam konteks pemecahan masalah. Sedangkan, Kurikulum Tingkat Satuan Pendidikan (KTSP) berbasis kompetensi yang juga menghendaki pembelajaran tidak hanya mempelajari tentang konsep, teori, dan fakta tetapi juga aplikasi dalam kehidupan sehari-hari, salah satunya adalah kemampuan pemecahan masalah (Trianto dalam Setyorini, dkk., 2011).

Berdasarkan hasil observasi yang dilakukan di SMA Negeri 1 Ketungau Tengah diperoleh informasi bahwa terdapat materi Fisika yang belum dipahami dengan baik oleh siswa dan kemampuan pemecahan masalah yang masih kurang yang terlihat ketika siswa kebingungan dalam mengerjakan soal. Hal tersebut diperkuat berdasarkan hasil wawancara yang dilakukan terhadap guru mata pelajaran Fisika. Guru mata pelajaran Fisika menyatakan bahwa salah satu konsep yang masih belum dipahami secara maksimal oleh siswa adalah konsep hukum Archimedes.

Pembelajaran berbasis masalah atau problem-based learning (PBL) merupakan suatu pendekatan pembelajaran yang menggunakan masalah dunia nyata sebagai suatu konteks bagi siswa untuk belajar tentang berpikir kritis dan keterampilan pemecahan masalah serta untuk memperoleh pengetahuan dan konsep yang esensi dari materi pelajaran (Hudha, 2017; Mahmud dan Samad, 2015). PBL bertujuan untuk membantu peserta didik mempelajari konsep pengetahuan dan kemampuan memecahkan masalah dengan menghubungkan situasi masalah yang ada dalam dunia nyata (Fauziah, 2018; Wisudawati dan Sulistyowati, 2017) serta dapat meningkatkan hasil belajar siswa (Rupika dan Darmawan, 2018; Sulaiman, dkk., 2018).

Berdasarkan penjelasan yang telah diuraikan, maka dilakukan penelitian tentang pengaruh model pembelajaran problem-based learning terhadap pemahaman konsep dan pemecahan masalah materi Hukum Archimedes di kelas XI IPA SMA Negeri 1 Ketungau Tengah. 


\section{METODE}

Metode penelitian yang digunakan adalah metode eksperimen. Bentuk penelitian yang digunakan adalah quasi experimental designs dengan rancangan penelitian nonequivalent groups posttest-only. Populasi penelitian adalah seluruh siswa kelas XI IPA SMA Negeri 1 Ketungau Tengah yang terdiri dari 2 kelas. Pengambilan sampel menggunakan cluster random sampling degan cara pengundian untuk menentukan kelas XI IPA1 dan XI IPA2 sebagai kelas perlakuan. Adapun dari hasil pengundian tersebut diperoleh kelas XI IPA2 sebagai kelas eksperimen dan kelas XI IPA1 sebagai kelas kontrol.

Teknik pengumpulan data digunakan untuk mendapatkan nilai pemahaman konsep dan pemecahan masalah materi Hukum Archimedes. Teknik pengukuran untuk menentukan nilai posttest (tes akhir) terhadap pemahaman konsep dan pemecahan masalah Hukum Archimedes. Bentuk tes kemampuan pemahaman konsep yang digunakan berupa pilihan ganda yang terdiri dari 15 butir soal dan kemampuan pemecahan masalah berupa uraian yang berjumlah 4 butir soal. Teknik analisis data yang digunakan adalah analisis data kuantitatif yaitu statistik deskriptif dan MANOVA dua arah. Statistik deskriptif dilihat dari rerata, standar deviasi, varian, dan presentase.

Tabel 1 Kategori Persentase Nilai Butir Soal

\begin{tabular}{cc}
\hline Nilai & Kategori \\
\hline $81-100$ & Sangat baik \\
$61-80$ & Baik \\
$41-60$ & Cukup \\
$21-40$ & Kurang \\
$0-20$ & Sangat kurang \\
\hline & (Arikunto, 2011)
\end{tabular}

\section{HASIL DAN PEMBAHASAN}

Deskripsi data hasil posttest kemampuan pemahaman konsep dan kemampuan pemecahan masalah kelas kontrol yang menggunakan model pembelajaran konvensional dan kelas eksperimen diberikan problem-based learning disajikan pada tabel berikut. 
Tabel 2 Deskripsi Data Posttest Kemampuan Pemahaman Konsep dan Kemampuan Pemecahan Masalah

\begin{tabular}{lcccc}
\hline \multirow{2}{*}{ Nilai } & \multicolumn{2}{c}{$\begin{array}{c}\text { Kemampuan } \\
\text { Pemahaman Konsep }\end{array}$} & \multicolumn{2}{c}{$\begin{array}{c}\text { Kemampuan Pemecahan } \\
\text { Masalah }\end{array}$} \\
\cline { 2 - 5 } & $\begin{array}{c}\text { Kelas } \\
\text { Eksperimen }\end{array}$ & $\begin{array}{c}\text { Kelas } \\
\text { Kontrol }\end{array}$ & $\begin{array}{c}\text { Kelas } \\
\text { Eksperimen }\end{array}$ & $\begin{array}{c}\text { Kelas } \\
\text { Kontrol }\end{array}$ \\
\hline Sampel & 18 & 19 & 18 & 19 \\
Rata-rata & 52,59 & 35,09 & 69,80 & 10,04 \\
Standar deviasi & 7,54 & 10,39 & 24,47 & 5,37 \\
Varian & 56,91 & 107,88 & 598,56 & 28,83 \\
Persentase & 52,59 & 35,09 & 69,80 & 10,04 \\
\hline
\end{tabular}

Berdasarkan hasil posttest kelas eksperimen disimpulkan bahwa kemampuan pemahaman konsep siswa "Cukup" dan pemecahan masalah siswa "Baik" setelah diterapkannya problem-based learning. Sedangkan, hasil posttest kelas kontrol disimpulkan bahwa kemampuan pemahaman konsep siswa "Kurang" dan pemecahan masalah siswa "Sangat Kurang" setelah diterapkannya model pembelajaran konvesional pada materi Hukum Archimedes di kelas XI IPA SMA Negeri 1 Ketungau Tengah.

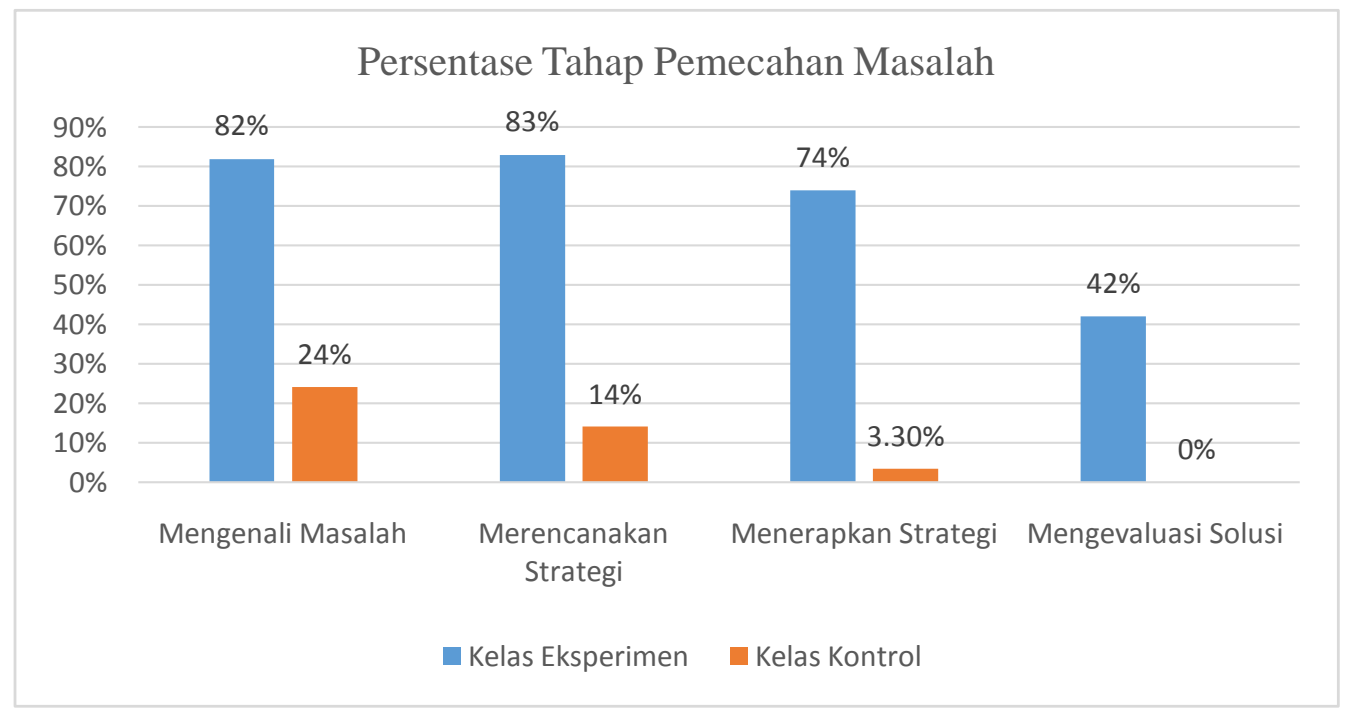

\section{Gambar 1 Tahap Pemecahan Masalah}

Gambar 1 memperlihatkan bahwa: (1) Tahap mengenali masalah kelas eksperimen lebih besar dari kelas kontrol; (2) Tahap merencanakan strategi kelas 
eksperimen lebih besar dari kelas kontrol; (3) Tahap menerapakan strategi kelas eksperimen lebih besar dari kelas kontrol; dan (4) Tahap mengevaluasi solusi kelas eksperimen lebih besar dari kelas kontrol.

Analisis pengaruh problem-based learning terhadap pemahaman konsep dan pemecahan masalah materi Hukum Archimedes di kelas XI IPA SMA Negeri 1 Ketungau Tengah menggunakan persamaan MANOVA dua arah. Adapun hasil analisis MANOVA dua arah hasil terlihat pada tabel berikut.

Tabel 3 Hasil Uji Signifikansi MANOVA

\begin{tabular}{llc}
\hline \multicolumn{1}{c}{ Effect } & Signifikansi \\
\hline Kelas Kontrol & Pillai's Trace & 0,075 \\
& Wilks' Lambda & 0,075 \\
& Hotelling's Trace & 0,075 \\
& Roy's Largest Root & 0,075 \\
\hline Kelas Eksperimen & Pillai's Trace & 0,000 \\
& Wilks' Lambda & 0,000 \\
& Hotelling's Trace & 0,000 \\
& Roy's Largest Root & 0,000 \\
\hline
\end{tabular}

Hasil analisis menyajikan uji signifikansi multivariat. Pada kelas kontrol dan kelas eksperimen perbedaan centroid empat kategori ditinjau dari koefisien Pillai's Trance, Wilks' Lambda, Hotelling's Trace, dan Roy's Largest Root. Koefisien uji jika ditransformasikan ke distribusi Fisher atau uji F, maka semuanya signifikansi $\alpha=0,05$. Pada kelas kontrol nilai signifikansi 0,075 $>0,05$, sehingga dapat disimpulkan bahwa tidak terdapat pengaruh model pembelajaran konvensional terhadap kemampuan pemahaman konsep dan pemecahan masalah. Sedangkan pada kelas eksperimen nilai signnifikansi $0,000<0,05$, sehingga dapat disimpulkan bahwa terdapat pengaruh problem-based learning terhadap kemampuan pemahaman konsep dan pemecahan masalah.

Berdasarkan Tabel 2, diketahui bahwa kemampuan pemahaman konsep siswa "Cukup" dan pemecahan masalah siswa "Baik" setelah diterapkannya problem-based learning pada materi Hukum Archimedes di kelas XI IPA SMA Negeri 1 Ketungau Tengah di kelas eksperimen. Hal tersebut dikarenakan siswa mampu berpikir secara kritis, lateral, dan sistemik dalam menyelesaikan masalah setelah diterapkannya problem-based learning. Hal tersebut sesuai dengan 
pendapat Rusman (2010) bahwa problem-based learning memungkinkan siswa mengembangkan keterampilan berpikir dalam memecahkan masalah.

Kemampuan pemahaman konsep siswa "Kurang" dan pemecahan masalah siswa "Sangat Kurang" setelah diterapkannya model pembelajaran konvesional pada materi Hukum Archimedes kelas XI IPA SMA Negeri 1 Ketungau Tengah di kelas kontrol. Rendahnya kemampuan pemecahan masalah disebakan oleh pembelajaran yang hanya berpusat pada guru. Hal tersebut dengan pendapat Ahmadi (Khoirullah, 2016) yang menyatakan bahwa model pembelajaran konvensional menyandarkan pada hafalan belaka, penyampaian informasi lebih banyak dilakukan oleh guru, siswa secara pasif menerima informasi, pembelajaran sangat abstrak dan teoretis serta tidak bersandar pada realitas kehidupan, memberikan hanya tumpukan beragam informasi kepada siswa, cenderung fokus pada bidang tertentu, waktu belajar siswa sebagaian besar digunakan untuk mengerjakan buku tugas, mendengar ceramah guru, dan mengisi latihan (kerja individual).

Data pada Tabel 2 juga memperlihatkan bahwa persentase kemampuan pemahaman konsep kelas eksperimen 52,59\% lebih besar dari kelas kontrol $35,09 \%$. Sedangkan, persentase kemampuan pemecahan masalah kelas eksperimen $69,80 \%$ lebih besar dari kelas kontrol 10,04\%. Berdasarkan interpretasi MANOVA dua arah tidak terdapat pengaruh model pembelajaran konvensional terhadap kemampuan pemahaman konsep dan pemecahan masalah dan terdapat pengaruh problem-based learning terhadap kemampuan pemahaman konsep dan pemecahan masalah. Sehingga dapat disimpulkan bahwa kemampuan pemahaman konsep dan kemampuan pemecahan masalah siswa yang diberikan problem-based learning lebih baik dari model pembelajaran konvesional pada materi Hukum Archimedes di kelas XI IPA SMA Negeri 1 Ketungau Tengah.

Berdasarkan Tabel 3, pada kelas kontrol disimpulkan bahwa tidak terdapat pengaruh model pembelajaran konvensional terhadap kemampuan pemahaman konsep dan pemecahan masalah. Sedangkan, pada kelas eksperimen disimpulkan bahwa terdapat pengaruh problem-based learning terhadap kemampuan 
pemahaman konsep dan pemecahan masalah. Oleh karenanya, pemilihan model pembelajarn yang tepat sangat diperlukan dalam proses pembelajaran.

Problem-based learning adalah model pembelajaran yang membuat siswa terlibat aktif pada proses pembelajaran. Sehingga, problem-based learning sangat memengaruhi kemampuan pemahaman konsep dan kemampuan pemecahan masalah. Hal tersebut sesuai dengan pendapat Hertiavi, dkk. (2010) yang menyatakan bahwa cara dan strategi guru melaksanakan proses pembelajaran sangat berpengaruh terhadap keberhasilan kegiatan pembelajaran. Hamid (2007) menyatakan bahwa kegiatan pembelajaran yang aktif, kreatif, dan menyenangkan dapat menciptakan lingkungan yang rileks, tidak membuat siswa menjadi stres, dan dapat mencapai keberhasilan yang tinggi.

\section{SIMPULAN}

Berdasarkan hasil analisis data penelitian, maka disimpulkan: (1) Kemampuan pemahaman konsep dan pemecahan masalah siswa yang menggunakan problem-based learning lebih baik dari model pembelajaran konvesional pada materi Hukum Archimedes di kelas XI IPA SMA Negeri 1 Ketungau Tengah; (2) Kemampuan pemahaman konsep siswa "Cukup" dan pemecahan masalah siswa "Baik" setelah diterapkannya problem-based learning pada materi Hukum Archimedes di kelas XI IPA SMA Negeri 1 Ketungau Tengah; (3) Kemampuan pemahaman konsep siswa "Kurang" dan pemecahan masalah siswa "Sangat Kurang" setelah diterapkannya model pembelajaran konvesional pada materi Hukum Archimedes di kelas XI IPA SMA Negeri 1 Ketungau Tengah; dan (4) Terdapat pengaruh problem-based learning terhadap pemahaman konsep dan pemecahan masalah materi Hukum Archimedes di kelas XI IPA SMA Negeri 1 Ketungau Tengah.

\section{DAFTAR PUSTAKA}

Arikunto, S. 2011. Dasar-Dasar Evaluasi Pendidikan. Jakarta: Bumi Aksara.

Darma, Y. \& Imam, S. 2014. Strategi Heuristik dengan Pendekatan Metakognitif dan Investigasi terhadap Kemampuan Pemecahan Masalah Matematis 
Ditinjau dari Kreativitas Siswa Madrasah Aliyah. Jurnal Pendidikan MIPA, 15(2): 110-119.

Fauziah, U. 2018. Problem Based Learning Terintegrasi Karakter Religius pada Materi Sistem Reproduksi Manusia. Jurnal Pendidikan Informatika dan Sains, 7(1): 91-106.

Hamdani, D., Kurniati, E., \& Sakti, I. 2012. Pengaruh Model Pembelajaran Generatif dengan Menggunakan Alat Peraga terhadap Pemahaman Konsep Cahaya Kelas VIII di SMP Negeri 7 Kota Bengkulu. Jurnal Exacta, 10(1): 79-88.

Hamid, A. 2007. Pembelajaran Melalui Pakem. Jurnal Pendidikan, 4(1): 3-5

Hertiavi, A. M., Langlang, H., \& Khanafiyah, S. 2010. Penerapan Model Pembelajaran Kooperatif Tipe Jigsaw untuk Peningkatan Kemampuan Pemecahan Masalah Siswa SMP. Jurnal Pendidikan Fisika Indonesia, 6(1): 53-57.

Hudha, M. N. 2017. Authenthic Problem Based Learning (APBL) untuk Meningkatkan Kemampuan Berpikir Siswa. Jurnal Pendidikan Matematika dan IPA, 8(1): 64-70.

Khoirullah, M. E. 2016. Pembelajaran Concept Sentence dengan Pembelajaran Konvensional pada Mata Pelajaran Geografi Kelas X SMA Al-Huda Jati Agung Tahun Pelajaran 2014/2015. Skripsi Strata pada FKIP Universitas Lampung: Tidak diterbitkan.

Mahmud, N. \& Samad, R. 2015. Penerapan Model Pembelajaran Berbasis Masalah untuk Meningkatkan Hasil Belajar IPA pada Siswa SD Kelas IV SD 48 Kota Ternate. Jurnal Pendidikan, 13(2): 508-5016.

Mukminan. 2013. Implementasi Kurikulum 2013. Yogyakarta: Universitas Negeri Yogyakarta.

Nafiah, M. 2016. Pengaruh Model Pembelajaran Problem Based Learning terhadap Kemampuan Pemecahan Masalah dalam Materi Kalor di Kelas VII MTs Mathla'ul Anwar Pontianak. Skripsi Strata Satu pada FPMIPATEK IKIP-PGRI Pontianak: Tidak diterbitkan.

Nursyarifah, R., Rochman, C., Nasrudin, D., Yuningsih, K. E., \& Latif, A. 2018. Efektivitas Proses Pembelajaran Fisika Menggunakan Pendekatan Saintifik. Jurnal Wahana Pendidikan Fisika, 3(2): 13-18.

Rupika \& Darmawan, H. 2018. Pembelajaran Fisika Menggunakan Model Sains Teknologi Masyarakat dan Model Problem Based Learning Ditinjau dari Aktivitas Belajar Siswa pada Materi Listrik Dinamis di Kelas X SMA Negeri 1 Boyan Tanjung. Jurnal Pendidikan Sains dan Aplikasinya, 1(1): 22-26.

Rusman. 2010. Model-Model Pembelajaran Mengembangkan Profesionalisme Guru. Jakarta: Rajagrafindo Persada.

Sandra, E., Tandililing, E., \& Oktavianty, E. 2010. Analisis Pemahaman Konsep Siswa pada Materi Hukum Newton di SMA Negeri 3 Bengkayang. Jurnal Pendidikan dan Pembelajaran, 7(10): 1-8.

Setyorini, U., Sukiswo, S. E., \& Subali, B. 2011. Penerapan Model Problem Based Learning untuk Meningkatkan Kemampuan Berpikir Kritis Siswa SMP. Jurnal Pendidikan Fisika Indonesia, 7(1): 52-56. 
Sulaiman, Haji, A. G., \& Syukri, M. Pengaruh Model Problem Based Learning Berbantuan Information Technology terhadap Hasil Belajar Peserta Didik pada Materi Fluida Statis. Jurnal Pendidikan Matematika dan IPA, 9(2): 4964.

Sutarto, Wardhany, K. P. R., \& Subiki. 2014. Media Video Kejadian Fisika dalam Pembelajaran Fisika di SMA. Jurnal Pembelajaran Fisika, 2(4): 323-329.

Wisudawati, A. W. \& Sulisyowati, E. 2017. Metodologi Pembelajaran IPA. Jakarta: Bumi Aksara. 